\title{
Myiasis of Middle Ear and Eustachian Tube in a Neglected Child: Case Report
}

\author{
Mohammed T ${ }^{1 *}$, Islam MA'2 Islam MA'3 ${ }^{3}$ Lutfur Rahman $\mathrm{ASM}^{4}$, Chowdhury \\ $\mathrm{NH}^{5}$, Arefin $\mathrm{MK}^{6}$, Milki FU ${ }^{7}$ and Islam MS \\ ${ }^{1}$ Assistant Registrar ENT, Bangladesh Medical College Hospital, Bangladesh \\ ${ }^{2}$ Professor and Head, Department of Otolaryngology-Head \& Neck Surgery, Bangladesh Medical \\ College Hospital, Bangladesh \\ ${ }^{3}$ Registrar ENT, Bangladesh Medical College Hospital, Bangladesh \\ ${ }^{4}$ Resident Surgeon, Bangladesh Medical College Hospital, Bangladesh \\ ${ }^{5}$ Assistant Professor, Department of ENT, Bangladesh Medical College Hospital, Bangladesh \\ ${ }^{6}$ Otolaryngologist, Department of Otolaryngology, Dhaka Medical College Hospital, Bangladesh \\ ${ }^{7}$ Consultant ENT, Bangladesh Medical College Hospital, Bangladesh \\ ${ }^{8}$ Junior Consultant ENT, Bangladesh Medical College Hospital, Bangladesh
}

Case Report

Volume 5 Issue 2

Received Date: November 03, 2020

Published Date: November 18, 2020

DOI: $10.23880 /$ ooaj-16000203

*Correspondingauthor: Tareq Mohammed, AssistantRegistrar ENT, Bangladesh Medical College Hospital; Tel: +8801711527954; Email: tareqmohammad2013@gmail.com

\section{Abstract}

Aural myiasis is the infestation of the ear by larvae of flies. Commonly occurs in infected foul smelling wounds. Though common in animals, humans can become infected by close contact with animals or by directly by the female flies. Among the risk factors poor personal hygiene, poor socio-economic status, unconsciousness patients, neglected children's are common. Possible earliest removal is must. Aural miyasis is rare, only few cases have been reported so far. Here we present a 10 year child who is a diagnosed case of cerebral palsy presented with per aural bleeding. Endoscopic removal was done under general anesthesia in a secondary care hospital.

Keywords: Miyasis; Middle ear; Eustachian tube

\section{Abbreviations: ET: Eustachian Tube.}

\section{Introduction}

Greek word 'myia' means fly from which the word 'Myiasis' was derived. Myiasis is the infestation of fly larvae on living vertebrates like human or animals. It is more common in mammals specially animals. In human, commonly noticed in rural areas where there is more contact with animals. It is more common in tropical region. The life cycle of these larvae is variable depending on species, site of exposure etc.
Flies can leave their eggs on intact skin, wound, or necrotic tissue. Larvae's, just after hatching from the eggs enters to adjacent tissues where the remains, completes their life cycle and transforms into adult forms [1-5].

Clinical manifestation depends on site of involvement. Symptoms usually start when the deposited larvae start to feed on the surrounding tissue. In otolaryngology field Myiasis can occur at the ears, nose, paranasal sinuses, nasopharynx, oral cavity, and skin of the head and neck region [6]. Aural myiasis though rare can occur in both external and or middle 
ear. Humidity and warm weather is good environment for infestation. Identified risk factors are poor hygiene, low socioeconomic condition, paralysis, unconscious patients, and foul smelling wound.

Sign-symptom of aural Myiasis includes foreign body sensation, foul smelling otorrhoea, per aural bleeding, earache, itching, tinnitus, vertigo, hearing impairment [7]. Usually in most of the cases there remain an already perforated eardrum. Maximum number of cases there remains a history of long standing foul smelling ear discharge.

Here we present a case of 10 year old girl who was a diagnosed case of cerebral palsy came from a very poor (financially) family, brought by her parents with history of bleeding from right ear for 7 days with history of mucopurulent ear discharge for 2 years. There was no history of vomiting or fever over last few days. Patient was conscious but becomes irritable on touching the ear. There was no tenderness in mastoid region, mildly swollen and congested external auditory canal.

On otoscopic examination, there were multiple live maggots moving in deep meatus with active bloody ooze. The baby was so irritable to touch her ears. The maggots were removed endoscopically from the middle ear under general anesthesia. Total 8 larvae were removed by Crocodile forceps, among them 3 were removed from the Eustachian tube opening. It was difficult to remove the maggots from the Eustachian tube (ET) as they were moving in and out. Conventional turpentine oil soaked cotton was then kept for 5 minutes that might worked nicely. All maggots were slowly came out of ET and was successfully removed. Macroscopically these were cylindrical shaped with flattened ventral surface, 8 to $12 \mathrm{~mm}$ in length, whitish in color with grayish tinge. Irrigation with salaine-povidon iodine solution was helpful in removal of hidden maggots. The tympanic membrane was already perforated. Ossiclular chain was intact. There was no pus in middle ear during the procedure.

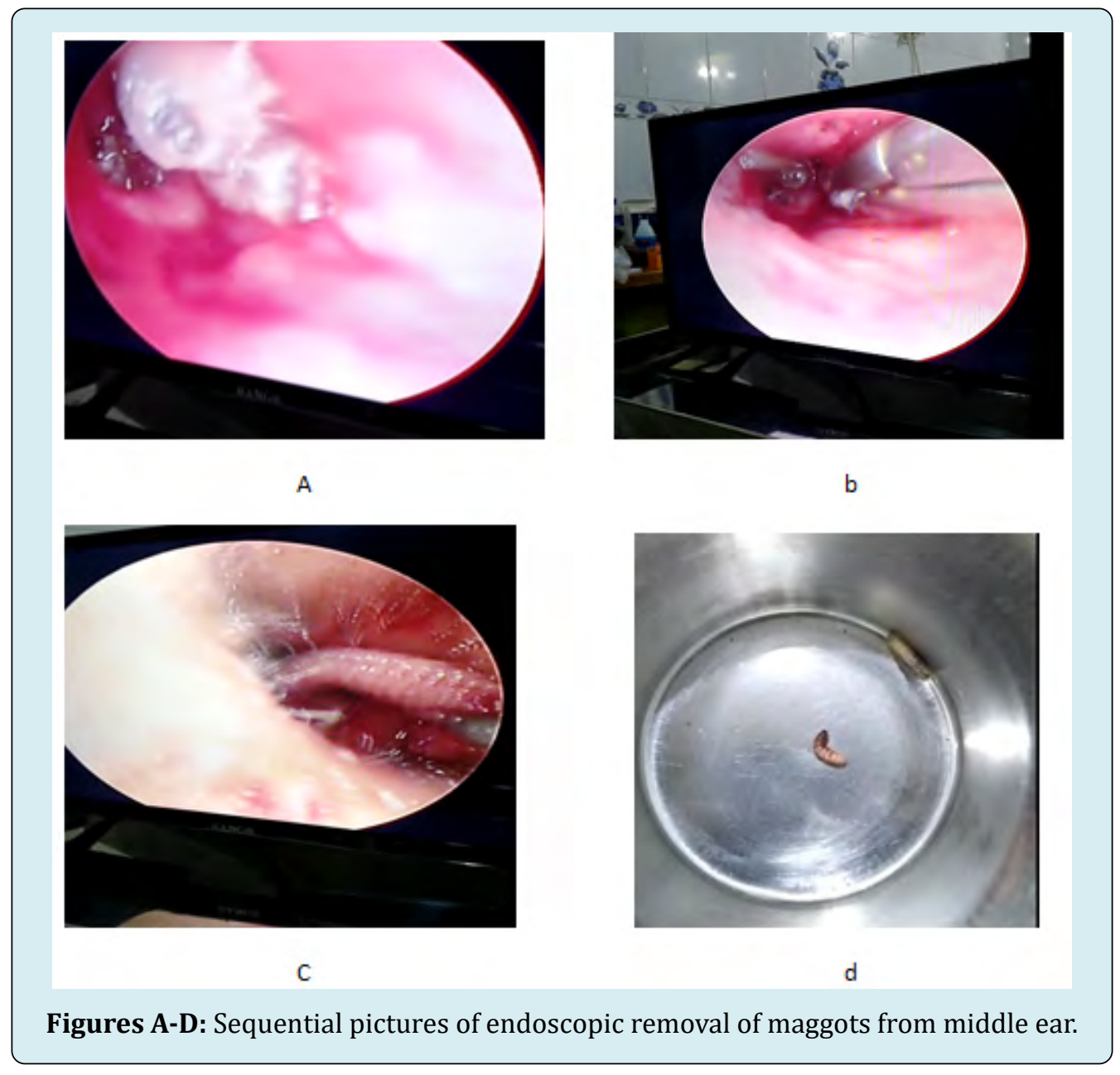




\section{Otolaryngology Open Access Journal}

\section{Discussion}

Myiasis of ears and nose are dangerous due to the capability of the larva to penetrate into the brain and can lead to meningitis due to inflammatory reaction and secondary bacterial infection. Otomyiasis can lead to deafness, meningitis even death usually occurs in preexisting otitis media but can occur without any prior history of ear discharge $[4,5,8]$.

Middle ear Myiasis removal is always challenging without an endoscope or microscope. There are multiple pores and cones where they can remain hidden like Eustachian tube, sinus tympani, additus to antrum. Live Myiasis can be visualized as they moves all around but dead myiasis that remains in Eustachian tube or antrum are not easy to visualize and its removal is much more challenging from this site. Although it is difficult to remove from these sites, it is the main treatment when feasible.

Though otoscopic examination is sufficient to reach the diagnosis, imaging study such as computed tomography is strongly indicated to evaluate the possible complication like destruction of mastoid, tagmen antri or tympani. Treatment is simply manual extraction of larvae as early as possible, irrigation with normal saline or iodine saline. Other options are topical application of ivermectinm, 70\% ethanol, 10\% chloroform, turpentine oi drops etc [9-12]. Aural suctioning and irrigation is helpful in killing and removal of hidden larvae. Prophylactic broad spectrum antibiotic should be started to prevent possible complications. Topical or systemic use of ivermactin is also recommended in different literatures $[10,11]$. W. magnifca is the commonest parasite responsible for human miyasis. To prevent unwanted fatal complication, early recognition and early removal is essential. Improvement of personal hygiene or treating the etiology behind the disease and reducing the risk factors is necessary to prevent recurrence.

\section{Conclusion}

We emphasize endoscopic removal is superior to microscope whenever possible, as endoscope can give easy visualization of hidden areas like sinus tympani, attic region and clear visualization of Eustachian tube region and thus makes the extraction more easy.

\section{References}

1. Khan I, Muhammad AY, Javed M (2006) Risk factors leading to aural myiasis. Journal of Postgraduate Medical Institute 20(4).

2. Joshua JB, Fitzpatrick N, Masood A, Crossland G, Hemi P (2015) Myiasis of the ear: a review with entomological aspects for the otolaryngologist. Ann Otol Rhinol Laryngol 124(5): 345-350.

3. Magliulo G, Gagliardi M, Amico DR (2000) Human aural myiasis. Otolaryngol Head Neck Surg 122(5): 777.

4. Wolf K, Johnson RA, Saavedra AP, Roh EK (2017) Arthropod Bites, Stings, and Cutaneous Infestations. Fitzpatrick's Color Atlas and Synopsis of Clinical Dermatology, $8^{\text {th }}$ (Edn.), McGraw-Hill Education New York, pp: 720-726.

5. Schwartz RA, Steen CJ (2012) Anthropod Bites and Stings. In: Goldsmith LA, et al. (Eds.), Fitzpatrick's Dermatology in General Medicine, $8^{\text {th }}$ (Edn.), McGraw-Hill Medical, New York, pp: 2599-2610.

6. Ibrahim AlJ (2015) Aural Myiasis, a Rare Cause of Earache. Case Reports in Otolaryngology.

7. Otoghile B, Oyeyemi AS, Amusa YB, Eziyi JAE, Ameye SA, et al. (2017) Otomyiasis in a Nigerian Tertiary Hospital: A Case Series and Literature Review. Nig Del Med J 1(2): 63-68.

8. Hernando AR, Haksari EL, Anggraini A, Samad, Setya W, et al. (2017) Nosocomial Aural Myiasis in a Sixteen-Hour Old-Indonesian Newborn. Current Pediatric Research 21(2): 197-200.

9. Cho JH, Kim HB, Cho CS, Huh S, Ree HI (1999) An aural myiasis case in a 54-year-old male farmer in Korea. Korean J Parasitol 37(1): 51-53.

10. Yuca K, Caksen H, Sakin YF, Sevil AY, Muzaffer K, et al. (2005) Aural myiasis in children and literature review. Tohoku J Exp Med 206(2): 125-130.

11. Ribeiro FAQ, Pereira CSB, Alves A, Marcon MA (2001) Tratamento da miíase humana cavitária com ivermectina oral. Rev Bras Otorrinolaringol 67(6): 755-761.

12. Singh NM, Bhatia SK, Singh G (2014) Maggots therapy in facilitating wound debridement: present status. Med J DY Patil Vidyapeeth 7(5): 639-642.

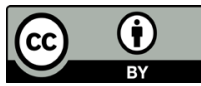

